\title{
PENGARUH MODEL PEMBELAJARAN VISUAL, AUDITORY, KINESTETHIC (VAK) TERHADAP PENINGKATAN KETERAMPILAN LARI JARAK PENDEK SISIWA KELAS IV SDN 3 PANCOR
}

\author{
Safruddin $^{1, *)}$, Nasaruddin ${ }^{2)} \&$ Nurul Kemala Dewi ${ }^{3)}$ \\ 1), 2), 3) Universitas Mataram, Mataram, Indonesia \\ E-mail: safruddin@unram.ac.id
}

\begin{tabular}{|c|c|}
\hline INFORMASI ARTIKEL & ABSTRAK \\
\hline $\begin{array}{l}\text { Article history } \\
\text { Received: September 10, } 2020 \\
\text { Revised: September 14, } 2020 \\
\text { Accepted: September 16, } 2020 \\
\text { Kata kunci: } \\
\text { model pembelajaran visual, } \\
\text { auditory, kinestethic, lari jarak } \\
\text { pendek }\end{array}$ & 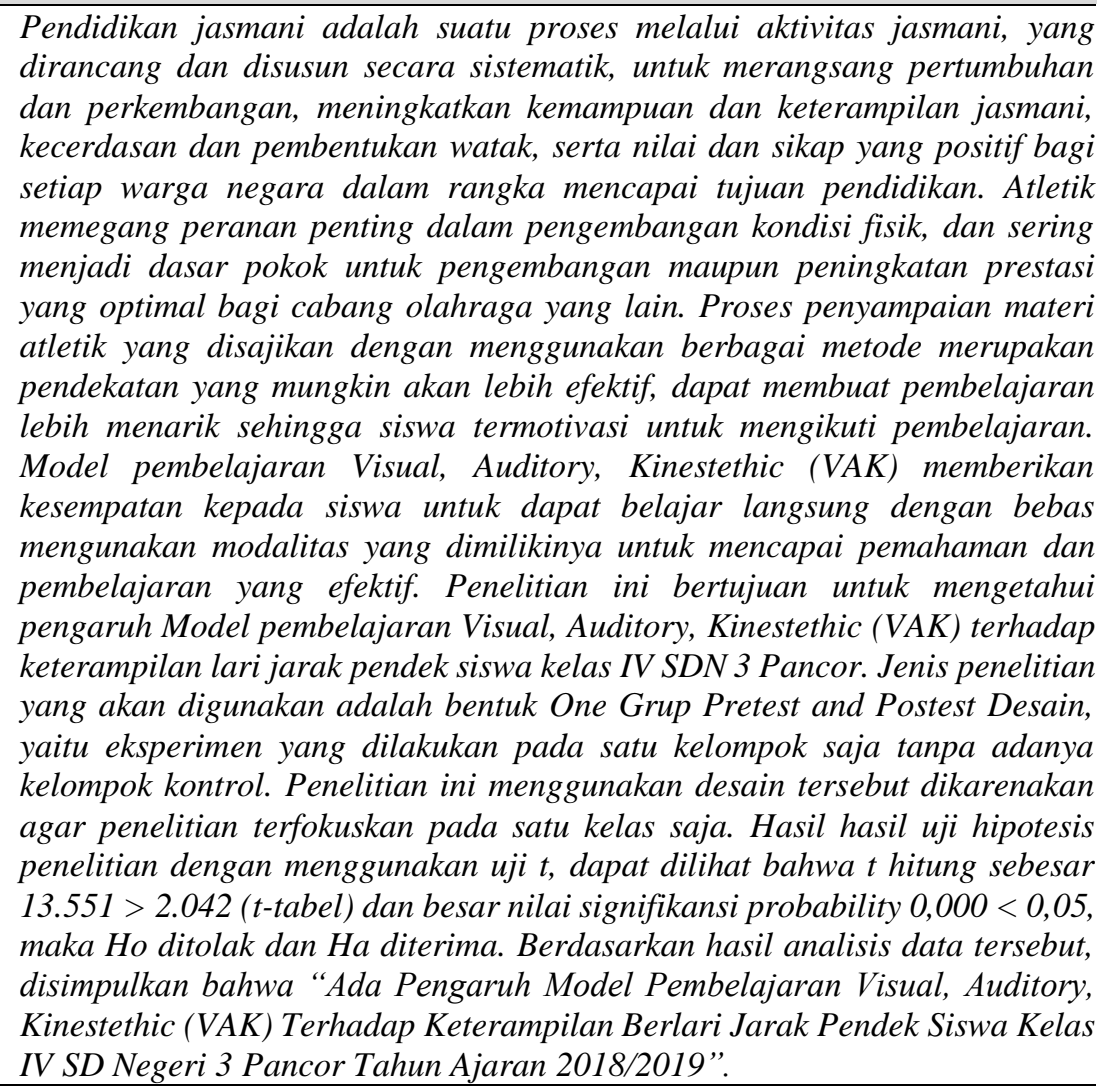 \\
\hline
\end{tabular}

\section{A. PENDAHULUAN}

Berdasarkan Undang-Undang Republik Indonesia Nomor 3 tahun 2005 tentang sistem Keolahragaan Nasional pasal 1 ayat 11 menyatakan bahwa olahraga pendidikan adalah pendidikan jasmani dan olahraga yang dilaksanakan sebagai bagian proses pendidikan yang teratur dan berkelanjutan untuk memperoleh pengetahuan, kepribadian, keterampilan, kesehatan, dan kebugaran jasmani.Olahraga berfungsi untuk mengembangkan kemampuan jasmani, rohani, dan sosial serta membentuk watak dan kepribadian bangsa yang bermartabat (UUD RI NO 3:2005). Pendidikan jasmani adalah suatu proses melalui aktivitas jasmani, yang 
dirancang dan disusun secara sistematik, untuk merangsang pertumbuhan dan perkembangan, meningkatkan kemampuan dan keterampilan jasmani, kecerdasan dan pembentukan watak, serta nilai dan sikap yang positif bagi setiap warga negara dalam rangka mencapai tujuan pendidikan.

Olahraga dapat membantu pertumbuhan dan perkembangan fisik manusia, khususnya anak-anak yang berada dalam masa pertumbuhan seperti anak sekolah dasar. Untuk membantu tumbuh dan kembang anak seklah dasar, pemerintah mengimplementasikan ke dalam kurikulumdalam bentuk mata pelajaran yaitu, mata pelajaran pendidikan jasmani, olahraga dan kesehatan. Dengan berolahraga siswa-siswa akan mengalami pertumbuhan dan perkembangan sesuai dengan umurnya. Salah satu bidang olahraga yang di ajarkan dalam pelajaran pendidikan jasmani di sekolah dasar adalah atletik, yang terdiri dari: jalan, lari, lompat, dan lempar.

Atletik merupakan salah satu materi pada mata pelajaran Pendidkan Jasmani yang wajib diberikan kepada para peserta didik mulai dari tingkat Sekolah Dasar sampai tingkat Sekolah Atas, sesuai dengan SK Mendikbud No. 0413/U/87. Atletik adalah gabungan dari beberapa jenis olahraga yang secara garis besar dapat dikelompokkan menjadi lari, lempar, dan lompat. Atletik memegang peranan penting dalam pengembangan kondisi fisik, dan sering menjadi dasar pokok untuk pengembangan maupun peningkatan prestasi yang optimal bagi cabang olahraga yang lain. Proses penyampaian materi atletik yang disajikan dengan menggunakan berbagai metode merupakan pendekatan yang mungkin akan lebih efektif, seperti halnya guruguru diharapkan dapat menggunakan metode pembelajaranyang tepat dan efektif unuk dapat membuat pembelajaran lebih menarik sehingga siswa termotivasi untuk mengikuti pembelajaran. Cabang atletik yang paling sering diajarkan di Sekolah Dasar ialah Lari.

Gerakan lari terdiri dari beberapa macam yaitu, lari jarak pendek (Sprint), Lari jarak menengah, lari jarak jauh, lari marathon,lari halang rintang dan lari estafet. Lari merupakan salah satu nomor cabang olahraga atletik yang paling sering diajarkan namun tidak mudah untuk di pelajari, terutama lari jarak pendek. Namun sebagian besar peserta didik tidak mengetahui teknik berlari yang benar, sehingga pada saat guru melakukan tes lari masih banyak peserta didik yang belum dapat melakukan dengan benar. Beberapa teknik dasar yang harus dipelajari dalam lari jarak pendek adalah teknik "start","berlari,"cara mencapai garis finish". Pada saat pelaksanaan lari jarak pendek sangat nampak bahwa peserta didik tidak begitu paham dengan teknik pelaksanaan gerakan lari sehingga hasil yang diinginkan tidak bisa tercapai dengan optimal. Hal ini dikarenakan penerapan metode pembelajaran yang kurang disukai atau kurang diminati oleh siswa pada materi lari jarak pendek, selain itu guru juga tidak memberikan konsep tentang materi berlari yang benar sebelum memerintahkan peserta didik untuk 
melakukan gerakannya sehingga sebagian peserta didik tidak melakukan gerakan berlari sesuai dengan prosedur yang ada.

Kondisi tersebut sesuai dengan hasil observasi di SD Negeri 3 Pancor yang dimana pada saat pembelajaran lari sebagian besar peserta didik belum memahamibagaimana cara melaksanakannya. Hal tersebut dikarenakan guru tidak menjelaskan konsep tentang bagaimana teknik lari yang benar, guru langsung menyuruh siswa untuk mempraktekkan lari sesuai dengan gerakan yang ditunjukkan oleh guru tersebut. Langkah-langkah yang dilakukan guru, ialah Guru mendemonstrasikan, kemudian peserta didik menirukan gerakan tersebut secara bergiliran. Pelaksanaan kegiatan memang teratur, tetapi terkesan kaku dan membosankan, karena kurang menarik perhatian peserta didik. Siswa hanya melakukan gerak pada saat giliran ia melakukan. Selebihnya mereka hanya duduk, berdiri, mengobrol dengan temanatau hal-hal lain diluar pembelajaran. Dalam hal ini guru dituntut untuk lebih kreatif dalam memberikan materi, sehingga peserta didik tidak bosan dalam belajar gerak terutama pada materi lari jarak pendek. Dibutuhkan variasi-variasi pembelajaran yang menyenangkan dan tentu saja menarik minat peserta didik sehingga mereka dapat meningkatkan keterampilan dalam berlari.

\section{B. METODE PENELITIAN}

Metode penelitian yang digunakan dalam penelitian seperti metode observasi, eksperimen, interview dan metode tes maupun metode -metode yang lainnya, sangat membutuhkan ketilitian dalam memilih metode yang bersangkutan, sehingga akan memperoleh hasil yang sesuai seperti yang diharapkan.

Penelitian ini termasuk penelitian eksperimen. Menurut Sugiyono (2016:6) bahwa metodeeksperimenmerupakan metode penelitian yang digunakan untuk mencari pengaruh treatment (perlakuan) tertentu. Jenis penelitian yang akan digunakan pada penelitian ini adalah bentuk One Grup Pretest and Postest Desain, yaitu eksperimen yang dilakukan pada satu kelompok saja tanpa adanya kelompok perbandingan. Penelitian ini menggunakan desai tersebut dikarenakan agar penelitian terfokuskan pada satu kelas saja.

Pelaksanaan penelitian dimulai dari pemberian pretes yang di lakukan awal penelitian. Pretes tersebut tes Keterampilan lari jarak pendek siswa. Pemberian pretes tersebut dilakukan untuk memperoleh data awal. Setelah pre-test diberikan, selanjutnya pemberian perlakuan diberikan kepada siswa. Perlakuan tersebut berupa pembelajaran lari jarak pendek dengan menggunakan Model Pembelajaran Visual, Auditory, Kinestethic (VAK). Selanjutnya setelah selesai diberikan perlakuan langkah selanjutnya ialah pemberian post-tes. Pemberian post-tes 
Safruddin, dkk. (2020). Pengaruh Model Pembelajaran...

tersebut dimaksudkan untuk menentukan metode latihan yang diujikan dapat meningkatkan keterampilan lari atau tidak.

\section{HASIL DAN PEMBAHASAN}

Hasil uji statistik terhadap keterampilan berlari jarak pendek siswa kelas IV SD Negeri 3 Pancor Tahun Ajaran 2018/2019 disajikan pada Tabel 1.

Tabel 1. Hasil Uji Statistik

\begin{tabular}{ccccc}
\hline No & $\begin{array}{c}\text { Uji Analisis } \\
\text { Data }\end{array}$ & Pengukuran & Signifikansi & Kesimpulan \\
& & & & \\
\hline 1 & Uji Normalitas & pretest & 0.155 & Normal \\
& & post-test & 0.080 & Normal \\
2 & Uji & & 0.722 & Homogen \\
3 & Homogenitas & & 0.000 & Signifikan \\
\hline
\end{tabular}

Penelitian ini bertujuan mengetahui "Pengaruh Model Pembelajaran Visual, Auditory, Kinestethic (VAK) Terhadap Keterampilan Berlari Jarak Pendek Siswa Kelas IV SD Negeri 3 Pancor Tahun Ajaran 2018/2019". Berdasarkan hasil hasil uji hipotesis penelitian dengan menggunakan uji t, dapat dilihat bahwa t hitung sebesar $13.551>2.042$ (t-tabel) dan besar nilai signifikansi probability $0,000<0,05$, maka Ho ditolak dan Ha diterima.

Model pembelajaran visual, auditory, kinestethik, adalah gaya belajar multi sensorik yang melibatkan tiga unsur gaya belajar yaitu penglihatan, pendengaran dan gerakan. Menurut Miftahul Huda (2017:289) model pembelajaran Visual, Auditory, Kinestethic (VAK) adalah gaya belajar multi sensorik yang melibatkan tiga unsur gaya belajar yaitu penglihatan, pendengaran dan gerakan. Pembelajaran dengan model ini mementingkan pengalaman belajar secara langsung dan menyenangkan bagi siswa.

Pemanfaatan dan pengembangan potensi siswa dalam pembelajaran ini harus memperhatikan kebutuhan dan gaya belajar siswa. bagi siswa dengan tipe visual, akan lebih mudah belajar dengan bantuan media dua dimensi seperti menggunakan grafik, gambar, chart, model dan semacamnya. Siswa auditory, akan lebih mudah belajar dengan pendengaran atau suatu yang diucapkan atau dengan medi audio. Sementara siswa dengan tipe kinestetik, akan mudah belajar sambil melakukan kegiatan tertentu, misalnya eksperimen, bongkar-pasang, membuat model, memanipulasi benda, dan sebagainya yang berhubungan dengan sistem gerak. Namun perlu dipahami bahwa belajar gerak berbeda dengan belajar pengetahuan, artinya belum tentu seseorang yang memiliki pengetahuan tentang suatu gerak akan secara mudah melakukan gerak yang diketahuinya. 
Pelaksanaan penelitian diawali dengan pemberian pre-test lari jarak pendek yang dilakukan berdasarkan penjelasan dari guru tentang cara-cara melakukan lari jarak pendek. Dari hasil pre -test terlihat bahwa teknik lari jarak pendek belum baik dilakukan, mulai dari aba-aba "bersediaa"- "siaap" - "yaaa", yaitu bagaimana cara meletakkan kedua tangan diatas garis start, bagaimana cara berlari, sampai dengan bagaimana cara melewati garis finish. Selanjutnya sebelum pelaksanaan pemberian perlakuan siswa ditunjukkan video, gambargambar, dan gerakan-gerakan teknik gerakan lari jarak pendek. Gerakan-gerakan tersebut menggambarkan bagaimana cara melakukan sikap start, dengan aba-aba "bersedia", "siaap", dan "yaa", hal tersebut menggambarakan sikap dan gerakan yang dilakukan secara berkesinambungan merupakan rangkaian gerak yang berhubungan antara gerakan yang satu dengan gerakan berikutnya, bagaimana cara bergerak sampai mencapai garis finish. Setelah informasi tersebut diberikan kemudian dilanjutkan dengan pelaksanaan pemberian perlakuan.

Model pembelajaran Visual, Auditory, Kinestethic (VAK) merupakan tiga modalitas yang dimiliki oleh setiap manusia. Ketiga modalitas tersebut kemudian dikenal sebagai gaya belajar. Gaya belajar merupakan kombinasi dari bagaimana seseorang dapat menyerap dan kemudian mengatur serata mengelola informasi. Pembelajaran dengan model ini mementingkan pengalaman belajar secara langsung dan menyenagkan bagi siswa.

Dalam pelaksanaan pemberian perlakuan terlihat beberapa sikap dan gerakan yang masih belum baik dilakukan oleh siswa sebagai subjek penelitian adalah seperti pada aba-aba "bersedia", sikap meletakkan kedua tangan digaris start sudah cukup baik dilakukan namun demikian pengaturan jarak antara garis start dengan ujung jari kaki belakang yang akan digunakan melakukan tolakan, hal ini akan sangat berpengaruh terhadapa daya tolakan kaki. Selanjutnya pada aba-aba "siiaaap", kesulitan yang masih dialami adalah gerakan kaki/tungkai pada saat gerakan mengangkat panggul, masih banyak siswa melakukan gerakan yang bersamaan antara mengangkat panggul dengan meluruskan kaki/tungkai yang akan digunakan untuk menolak, jika hal ini dilakukan akan berpengaruh terhadap tolakan kaki seperti halnya pada saat aba-aba "bersedia", seharusnya lutut jangan diluruskan terlalu cepat agar tolakan dapat dilakukan dengan lebih baik. Selain itu pandangan mata yang seharusnya tidak boleh lebih dari 2 meter, namun rata-rata mereka memandang terlalu jauh ke depan, bahkan beberapa orang siswa langsung melihat ke garis finish. Setelah aba-aba “yaaa”, kecepatan gerakan lari akan dipengaruhi oleh frekuensi dan lebar langkah, semakin banyak frekuensi dan semakin lebar gerakan langkah kaki yang dilakukan akan mendapatkan kecepatan yang semakin baik, tentunya gerakan ini diawali dengan tolakan maksimal dari ujung kaki. Untuk gerakan 
mencapai finish beberapa siswa masih melakukan gerakan lari tanpa mencondongkan anggota badan bagian atas kedepan/miring, hal ini juga sangat penting artinya dilakukan jika beberapa pelari memiliki kemampuan yang sama atau hampir sama, perbedaan siapa yang lebih cepat melewati garis finish akan ditentukan oleh teknik mencapai garis finish.

Selanjutnya setelah perlakuan yang dilakukan beberapa kali tampak kemajuan yang sangat berarti hal ini terlihat dari hasil post-test yang menunjukkan terjadinya peningkatan skor yang sangat berarti. Hal ini sesuai dengan pernyataan (DePorter, 199:112 dalam Aris Sohimin (2014:226)), yang menyatakan bahwa "pengalaman belajar secara langsung dengan cara belajar dengan mengingat (Visual) belajar dengan mendengar (Auditory), dan belajar dengan gerak dan emosi (Kinestethic), dapat meningkatkan pengetahuan dan keterampilan. Berdasarkan pendapat di atas, dapat disimpulkan bahwa model pembelajaran Visual, Auditory, Kinestethic (VAK) memberikan kesempatan kepada siswa untuk dapat belajar langsung dengan bebas mengunakan modalitas yang dimilikinya untuk mencapai pemahaman dan pembelajaran yang efektif.

\section{SIMPULAN}

Hasil hasil uji hipotesis penelitian dengan menggunakan uji t, dapat dilihat bahwa $\mathrm{t}$ hitung sebesar $13.551>2.042$ (t-tabel) dan besar nilai signifikansi probability $0,000<0,05$, maka Ho ditolak dan Ha diterima. Berdasarkan hasil analisis data tersebut, disimpulkan bahwa "Ada Pengaruh Model Pembelajaran Visual, Auditory, Kinestethic (VAK) Terhadap Keterampilan Berlari Jarak Pendek Siswa Kelas IV SD Negeri 3 Pancor Tahun Ajaran 2018/2019". Pembelajaran lari jarak pendek ada beberapa hal yang perlu dikuasi oleh peserta didik agar mendapatkan hasil yang baik dengan memberikan motivasi para mahasiswa untuk melakukan aktivitas pendidikan jasmani dan kesehatan dengan baik, memberikan materi polapola gerak dasar yang berhubungan dengan situasi yang terdapat dalam gerakan lari, seperti teknik dasar start, berlari, dan bagaimana mencapai garis finish, serta menggunakan pendekatan yang tepat dalam proses pembelajaran, salah satu model pembelajaran visual, auditory, kinestethic (VAK), merupakan salah satu model yang perlu digunakan oleh guru karena terbukti dapat meningkatkan keterampilan lari peserta didik.

\section{DAFTAR PUSTAKA}

Aji Sukma. 2016. Buku Olahraga Paling Lengkap. Jakarta: Bumi Pamulang - Bambu Apus. Budyanto Agus Krisno. 2016. Sintaks 45 Model Pembelajaran dalam Student Centred Learning (SCL). Malang: UMM 
Safruddin, dkk. (2020). Pengaruh Model Pembelajaran ...

DePorter, B \& Hernacki, M. 2015.Quantum Learning: Membiasakan Belajar Nyaman dan Menyenagkan. Bandung: Kaifa PT Mizan Pustaka

Candra Juli. 2018. Peningkatan Hasil Belajar Gerak Lokomotor dengan Pola Pendekatan Bermain SD AL Hanief Kota Bekasi, 01 (3): 57-66

Depdiknas. 2005. Panduan Pengembangan Moel Pembelajaran Berbasisi Kompetensi. Jakarta: Depdiknas

Huda Miftahul. 2017. Model-model Pengajaran dan Pembelajaran. Yogyakarta: Pustaka Pelajar

Komalasari, Kokom. 2010. Pembelajaran Kontekstual: Konsep dan Aplikasi. Bandung: Refika Aditama

Komarudin.2016. Hasil Penilaian Hasil Belajar Pendidikan Jasmani dan Olahraga.Bandung: PT Remaja Rosdakarya

Kunandar. 2007. Guru Profesional; Implementasi Kurikulum Tingkat SatuanPendidikan (KTSP) dan Persiapan Menghadapi Sertifikasi Guru, Jakarta: Raja Grafindo Persada Kurniawan Feri. 2011. Buku Pintar Olahraga. Jakarta: Niaga Swadaya.

Mulyono.2012. Strategi Pembelajaran Menuju Efetivitas Pemelajaran di Abad Gelobal. Malang: UIN-Maliki Press

Nelistya Anne. 2011. Menjadi Pemain Atletik yang Tangguh. Jakarta: Be Champion

Peraturan Pemerintah. Peraturan Pemerintah No 19 Tahun 2005 Tentang Standar Nasional Pendidikan. Jakarta.

Sagala, Syaiful. 2010. Konsep dan Makna Pembelajaran: Untuk Membantu Memecahkan Problematika Belajar Mengajar. Bandung: Alfabeta

Sugiyono. 2016. Metode Penelitian Kuantitatif, Kualitatif, dan R\&D. Bandung: Alfabeta Sohimin Aris. 2014. 68 Model Pembelajaran Inovatif dalam Kurikulum 2013. Yogyakarta:

Ar-Ruzz Media

Trianto.2010. Mendesain Model Pembelajaran Inovatif Progresif.Jakarta: Kencana Prenada Media

Undang-undang RI. 2005. Undang-undang RI Tahun 2005 Tentang Sistem Keolahragaan Nasional. Jakarta

Yudhawati \& deny Haryanti. 2011. Teori-Teori Dasar Psikologi Pendidikan. Jakarta: PT. Prestasi Purakaraya

Zafar dikdik. 2010. Mengajar dan Melatih Atlentik. Bandung: Remaja Rosdakarya. 